\title{
EFFICACY, IMPACT AND ENGLISH LEGAL HISTORY
}

\begin{abstract}
Theorists of law and of social policy distinguish between the efficacy and the impact of laws and legislation. Efficacy concerns the achievement of the effects intended by law-makers. Impact refers to the actual consequences. At times, the two diverge. Sometimes, it is only after a lengthy period that the impact is appreciated. The impact sometimes requires intervention by legislators or judges acting purposively in order to correct unforeseen or unfortunate consequences. The extent of judicial intervention is not always clear from the surviving records. This article argues that an awareness of the possibility of such occurrence is essential if legal history is to present the whole truth concerning legal developments.
\end{abstract}

Keywords: Legal history; legislation; efficacy; impact; judiciary; interpretation; purposive.

Mrs Lintott Now. How do you define history, Mr Rudge?

$\ldots$

Rudge How do I define history?

It's just one ... thing after another.

Alan Bennett, The History Boys, Act 2.

\section{INTRODUCTION}

Students of political and legal theory distinguish between the efficacy or intended effects of a policy and a policy's impact (e.g. Miers, Page 1990, 204-206). The efficacy or intended effects relate to the results which are intended by the proponents of the policy whereas the impact refers to the consequences which the implementation of the policy actually brings about in practice. Sometimes the two correspond; sometimes they do not. Where the policy has been implemented by means of making changes to the law, that is by means of legislation, the lack

" Queen's Counsel (honoris causa); Fellow of the Learned Society of Wales; Honorary Professor of Law, Bangor University. First Welsh Legislative Counsel (2007-2010); Professor of Law, Bangor Law School (2004-2007); Professor of Law, Cardiff Law School (2001-2004). The author wishes to thank the editors for their invitation to contribute to this publication and the anonymous peer reviewers for their helpful and useful criticism of an earlier version of the article which proved very constructive. The author alone is responsible for any errors, shortcomings or infelicities of style which may remain. 
of correspondence may only emerge after a considerable period of time has passed. Only with hindsight can it be seen that certain later developments are consequential upon the change made earlier, an additional change unforeseen by those responsible, a change in other words which was not an intended effect of the policy but part of its impact.

Some examples from modern times will serve to illustrate what is meant. It is best to begin with modern examples because the modern period furnishes more evidence in the form of preserved documentary sources than is the case with developments from earlier periods. Nevertheless, having presented the modern examples, some earlier developments will be examined in relation to which the question will be posed as to whether in those earlier examples one is also encountering changes which were unintended or unforeseen consequences of policies, that is part of those policies' impact rather than their efficacy. Sometimes the impact of a policy in this sense can undermine its intended effects. In such circumstances, the question arises of what should be done by those charged with its implementation, those administering justice in accordance with the laws concerned. Should they confine themselves to administering the law regardless of its unintended impact or should they seek to develop the law in accordance with the intended effects? In contemporary terms, this question could be posed by asking whether they should engage in purposive rather than literal application of the laws in question. This leads to the question which will also be asked as to what it is that legal historians study - the impact of legal changes as evidenced by the surviving records or the ideas which shaped the legislative policy - the effects which were intended, even if these are shrouded as a consequence of the impact.

\section{LAW, EQUITY AND THE JUDICATURE ACTS}

Until the middle of the nineteenth century, the common law of England was administered in the courts of common law - the courts of King's Bench, Common Pleas and Exchequer. In situations where the common law had been perceived not to provide a remedy or at least not an adequate remedy, litigants could turn to the Court of Chancery for a remedy. The rules which this court administered had become known as equity, a system of rules distinct from, but supplementing and complementing, those of the common law. ${ }^{1}$

The existence of two systems of rules could be inconvenient for litigants. A claimant for example who sought remedies for suffering as the result of

${ }^{1}$ The development into a system of rules took place gradually over several centuries. It was during the later fourteenth and fifteenth centuries that litigants would initially have petitioned for a remedy on the basis of the lack or inadequacy of a remedy at common law, while the refinement of equity into a system of rules occurred mainly between the later seventeenth and the early nineteenth century. 
the ongoing wrongful conduct of another would have to sue at common law to obtain damages but turn to equity in order to obtain an injunction to prevent the conduct continuing in the future. Likewise, a litigant complaining of an ongoing breach of contract would have to seek damages at common law for the losses caused thus far by the breach but in order to compel compliance in the future would have to turn to Chancery for the equitable remedy of specific performance. During the $1850 \mathrm{~s}$, legislation was enacted to overcome these inconveniences by allowing the courts of common law to grant equitable remedies such as injunctions and specific performance and allowing the Court of Chancery to award damages alongside its own equitable relief. ${ }^{2}$

The major change, however, occurred in the 1870s. The Judicature Acts of 1873-75 totally reshaped the English legal system. The Acts abolished the common law courts of King's Bench, Common Pleas and Exchequer, together with the Court of Chancery as well as the Admiralty Court and two courts established by statute in the 1850s - the Probate Court and the Divorce Court. These last two had assimilated within the secular jurisdiction causes of action which had previously been adjudicated within the ecclesiastical courts of the Church of England. ${ }^{3}$ The distinct jurisdictions of all of these now defunct courts were transferred to a new statutory creation, the Supreme Court of England and Wales, consisting of a High Court and a Court of Appeal. Business before the High Court was allocated to one of three divisions, but all three were equally competent to apply the rules of any of the jurisdictions which had previously been separate but which were now all incorporated within the jurisdiction of the new Supreme Court. ${ }^{4}$

Despite the new Supreme Court having jurisdiction to administer the rules both of common law and equity, the accepted view was that it was the administration of these two, erstwhile distinct, bodies of law which had been fused and not the bodies of law themselves. In other words, common law and equity remained distinct sets of rules even though they were now administered in the same court. They were not only distinct historically; they were intended to be distinct for the future as well. That was the intended effect of the legislation which created the new court and the fused jurisdiction.

\footnotetext{
${ }^{2}$ This was achieved by the Common Law Procedure Act 1854 and the Chancery Amendment Act 1858 .

${ }^{3}$ Both courts had wider jurisdictions that their ecclesiastical forerunners: the Probate Court derived parts of its succession jurisdiction from the former common law courts and Chancery, while the Divorce Court could, for instance, grant decrees of divorce a vinculo matrimonio which the Church courts did not.

${ }^{4}$ The Supreme Court of England and Wales was renamed the Senior Courts of England and Wales by the Constitutional Reform Act 2005 in order to prevent confusion with the new statutory creation, the Supreme Court of the United Kingdom, to which was transferred in 2009 the preexisting appellate jurisdiction of the House of Lords.
} 
However, what of its impact? Legal writers, describing the fusion of common law and equity as late as the start of the twenty-first century, continued to state that the 'orthodox' view was that 'only the jurisdictions have been fused' (Martin 2001, 20). A famous metaphor, coined by Ashburner, was frequently quoted: "the two streams of jurisdiction, though they run in the same channel, run side by side, and do not mingle their waters" (Ashburner 1933, 18). ${ }^{5}$ Famous the metaphor may be, but one would be fully entitled to enquire as to when the learned author had actually encountered such a phenomenon in the real world. When streams mingle, their waters are no longer distinguishable downstream.

One of the most distinguished English judges of the second half of the twentieth century, Lord Diplock, considered that the metaphor had 'become most mischievous and deceptive'. He believed that the Judicature Acts had fused not only the administration of the rules employed by the former separate jurisdictions, but that they had fused the systems of law themselves. He attributed the slowness of the legal professions to recognize this as being due to the 'innate conservatism of English lawyers' (United Scientific Holdings Ltd. v. Burnley Borough Council [1978] AC 904, 925).

The remark is telling. Had the Acts required the fusion of the previous separate systems, this would have been stated in terms or at least been a necessary implication. That the courts had been able for a century to hold that the systems themselves were not fused but only their administration suggests that the greater fusion was not an intended effect of the legislation. Equally, the fact that some could believe that the greater fusion was possible indicates that the Acts had not limited their effect to the lesser fusion. In that the greater fusion was not an intended consequence, developments which are based on its having occurred are predicated upon its having been an impact of the legislation.

Examples of that impact can be found. In Lloyds Bank v. Bundy, the Court of Appeal - and in particular Lord Denning MR - drew on equitable rules regarding undue influence and rules from the erstwhile Admiralty jurisdiction to state a principle 'of English law' ([1975] QB 326. Discussed in Watkin 1977). In Foskett v. McKeown, Lord Millett in the House of Lords expressed his dissatisfaction with the continued demarcation between the process of tracing property at common law and tracing property in equity. He stated that:

"there is nothing inherently legal or equitable about the tracing exercise. There is thus no sense in maintaining different rules for tracing at law and in equity. One set of tracing rules is enough. The existence of two has never formed part of the law in the United States... There is certainly no logical justification for allowing any distinction between them to produce capricious results in cases of mixed substitutions by insisting on the existence of a fiduciary relationship as a precondition of applying equity's tracing rules" ([2000] 2 WLR 1299, 1324). ${ }^{6}$

${ }^{5}$ The first edition by Walter Ashburner himself had been published in 1902.

${ }^{6}$ Whereas the legal owner of property at common law could follow the property into the hands of another, he was not able to trace the property should it become mixed, for example with that 
Many took his remarks as amounting to an indication that he would restate, and thereby in effect fuse, the relevant rules as rules of English law should the opportunity be given him through an appeal involving the issue to come before him in the highest appellate court. Unfortunately for proponents of the greater fusion, no such case materialized before he retired from the bench in 2004 and therefore in this instance the impact did not materialize. Nevertheless, Lord Millet's words make it clear that such an impact is possible - a possibility created by the fusion of law and equity regardless of whatever effect was originally intended by that fusion.

In both these cases, one sees the willingness of judges to recognize that, whatever its intended effect, the impact of the legislation in question permitted them to develop the law in a particular way. Some would decline to take advantage of such an opportunity on the basis that such changes to the law should only take place if expressly intended by the legislature or at least that the change was a necessary implication of the legislature's intentions; others however are prepared to embrace the opportunity for change which the legislation's impact has permitted.

\section{THE ABOLITION OF THE FORMS OF ACTION}

One of the most celebrated instances of a judge being prepared to develop the law on the basis of the impact of much earlier legislation is the speech of Lord Atkin in the House of Lords in the case of Donoghue v. Stevenson ([1932] AC 562). The case came before the House of Lords on appeal from Scotland, but the decision is regarded as creating the so-called tort of negligence in English law. Until 1832 - that is a century prior to the litigation - litigants making a claim at common law had to select a writ which was suitable for their claim. If they selected a writ which was not appropriate, they would be wrong suited and their claim dismissed. These writs were collectively known as the forms of action at common law. The rules of liability at common law had developed as rules pertinent to the several writs rather than as rules of general application. ${ }^{7}$

other's own. In equity on the other hand, the beneficial owner of property could trace the property into a mixed fund, but tracing was only permitted in equity where the beneficial owner was within a fiduciary relationship such as being the beneficiary under a trust. The different rules reflected conditions existing prior to the merging of the erstwhile jurisdictions.

${ }^{7}$ Despite regular protestations from the judiciary that the boundaries between the forms of action needed to be maintained to prevent confusion, the distinctions relevant to choosing the correct writ were not always easy to apply. For instance, the distinction between the writs of trespass for direct, immediate wrongs and trespass on the case for consequential harm proved difficult in cases of road traffic accidents which could be viewed as instances where injury was occasioned by the defendant driving a vehicle into the plaintiff (trespass) or as instances in which the plaintiff suffered harm as a consequence of the defendant's negligent driving (case). 
The Uniformity of Process Act 1832 abolished the several writs. Henceforth, only one writ of summons was to be used. However, the Act required the plaintiff to mention in the writ of summons upon which of the erstwhile forms of action the claim was based. The Common Law Procedure Act 1852 expressly provided that such mention of a former form of action was no longer necessary. ${ }^{8}$ Nevertheless, English lawyers, displaying perhaps what Lord Diplock called their 'innate conservatism' - continued to distinguish between various claims at common law for wrongful damage in terms of the now defunct individual writs. Thus, textbook writers continued to treat of separate torts of trespass, case, nuisance, detinue, conversion, and so on, retaining the distinct rules of liability for each of the torts which corresponded to the abolished writs. Whether or not negligence, for instance, was a necessary ingredient for a successful claim depended upon the tort (corresponding to the former writ) which it was claimed had been committed.

The House of Lords in Donoghue v. Stevenson was faced with such a claim. The claimant had purchased a product from a retailer with whom she therefore had a contract. The product was found to be contaminated. Having been sold in a sealed receptacle, the contamination could not have been the fault of the retailer, but must have occurred during the process of manufacture. The claimant chose to sue the manufacturer. It was argued that she could not sue the manufacturer for wrongdoing because she had a claim in contract against the retailer. In other words, she had to choose the appropriate category of claim albeit that the forms of action upon which the categories were based had been abolished.

By a bare majority of three to two, the Law Lords refused to be confined by the 'innate conservatism of English lawyers'. 'The effect of the abolition of the forms of action may only have been to make it unnecessary to select a writ or to refer to a particular cause of action in the writ of summons, but Lord Atkin saw that the impact of the reform might be far greater. He saw that one could unify the principles of liability which had previously been specific to each writ and thereby state a general principle of tortious liability in English law.

He said:

"the duty which is common to all the cases where liability is established must logically be based upon some element common to the cases where it is found to exist...

....in English law there must be, and is, some general conception of relations giving rise to a duty of care, of which the particular cases found in the books are but instances"

and he went on to expound the neighbour principle which duly became the basis of liability for negligence in the English law of torts. Lord Atkin refused to be cowed by that 'innate conservatism' which Maitland, the founding father of the modern study of English legal history, had summarised in his aphorism "the forms

\footnotetext{
${ }^{8}$ Common Law Procedure Act 1852, 3.

${ }^{9}$ Tellingly, the two dissenting judges were English. They were outvoted by two Scottish judges and Lord Atkin, who was an Australian-born Welshman.
} 
of action we have buried, but they still rule us from their graves" (Maitland 1909, 296). In a later case, Lord Atkin developed Maitland's metaphor, manifesting his awareness of the significance of what he had done, saying: "When these ghosts of the past stand in the path of justice clanking their mediaeval chains the proper course for the judge is to pass through them undeterred" (United Australia Ltd. v. Barclays Bank Ltd. [1941] AC 1, 29). The abolition of the boundaries between the erstwhile writs also allowed the boundaries between the categories of tort based upon them to be overridden..$^{10}$ Whatever effect it was intended to achieve by abolishing the forms of action, the impact of their abolition has been to allow the English law of liability for tortious wrongdoing to be changed in quite a fundamental manner.

One can perhaps see the fulfilment of this potential in the case of Letang v. Cooper in 1964 ([1965] QB 232). In that case, Lord Denning MR in the Court of Appeal declined "to go back to the old forms of action" to deal with the issues before him. He asserted that they had "served their day". "They did", he said, "at one time form a guide to substantive rights; but they do so no longer". Whereas in earlier years, causes of action reflected the previously existing forms, "we divide the causes of action now according as the defendant did the injury intentionally or unintentionally" (Letang v. Cooper [1965] QB 232, 240). Whatever the intended effect of the abolition of the forms of action, the impact has been to allow the courts to restate the English law of torts regarding personal injuries in terms of the degree of fault attaching to the alleged wrongdoer.

\section{IMPACT AND PURPOSIVE INTERPRETATION OF LEGISLATION}

Over the last half century, the United Kingdom's membership of the European Union has also contributed to the fund of examples of legislative impact as opposed to efficacy. Entry into what was then the Common Market or the European Communities involved the United Kingdom accepting that its laws must be compatible with those of the European Union and that those laws would enjoy primacy over the domestic laws of the UK. However, the impact of that step has been greater than that, with consequences which were possibly neither intended nor foreseen when the European Communities Act 1972 became law.

The traditional approach to statutory interpretation in English law had for some centuries been literal, as opposed to the logical or purposive approach to legislative interpretation in the civilian jurisdictions of the six founding member states. The British judiciary realized, however, that to apply a literal

${ }^{10}$ It is pertinent to note once more that Donoghue v Stephenson was an appeal from Scotland, where the relevant law had not been developed in the context of forms of action, a circumstance which may have provided both inspiration and impetus to liberate English law from its 'mediaeval chains'. 
approach to the interpretation of EU law might and probably would result in the interpretation of EU law in UK courts being at variance with that in the courts of the other member states. Accordingly, it was decided that a purposive approach should be adopted when dealing with EU law in the same manner that such an approach had previously been used in the interpretation of international treaties. To discover the purpose of an item of EU legislation, the British judiciary also realized that courts in the other countries followed the civilian style of utilizing travaux préparatoires, background material pertinent to an understanding of what the legislation sought to achieve. This approach was diametrically opposed to English law's utter refusal to consult the parliamentary record for illumination when interpreting a statute.

Having taken the step of employing a purposive approach to the interpretation of EU law and having been prepared to consult travaux préparatoires in doing so, and having experienced the benefits of so doing, it was not long before the courts began to question why the same approach should not be adopted and the same benefits sought when interpreting domestic UK legislation. The result - the impact - has been a steady growth in the use of a purposive approach to statutory interpretation and the abandonment of the refusal to use background material to assist in the task. ${ }^{11}$

In all these instances, the impact of UK membership of the EU upon its domestic law has been greater than the intended effects of the relevant legislation passed upon joining. ${ }^{12}$

\section{SOME QUESTIONS FOR LEGAL HISTORY}

In all three of the examples given above, drawn from the relatively recent legal history of England and Wales, it can be seen that the impact of a piece of legislation - and of the policy behind that legislation - has been greater than the effects which the legislation was intended to achieve. One can see too that the legal professions and the judiciary in particular play a significant rôle in determining whether those impacts are to be countenanced or not. Whereas an 'innate conservatism' may be encountered in some quarters, in others there is a readiness to embrace the opportunity afforded by a piece of legislation to take

${ }^{11}$ The decisive step to allow reference to Parliamentary Debates was taken in Pepper (Inspector of Taxes) v. Hart [1993] AC 593. The question of when it is appropriate to consult additional background materials is discussed in Lord Nicholls' speech in Wilson v. First County Trust Ltd. (No. 2) [2003] UKHL 40; [2004] 1 AC 816. The application of the EU's principle of proportionality to subordinate legislation made to implement EU law within the UK has also resulted in the principle being applied to subordinate legislation generally within the UK.

${ }^{12}$ It seems very unlikely that if and when UK leaves the EU, there will be any appetite among the legal professions for the reversal of these impacts. 
the law in a direction which may or may not have been either desired or foreseen by those who framed it.

Questions therefore arise as to whether, in periods when the documentary evidence is not so great, legal historians should be aware of such tensions possibly having existed, and also what part that awareness should play in their interpretation of legal developments. The discussion will, therefore, now move to examples from earlier centuries to illustrate circumstances in which it was or may have been the impact rather than the effect of legislation or policy which shaped legal development.

\section{THE EFFICACY AND IMPACT OF THE STATUTE OF USES}

The Statute of Uses of 1536 is one of the famous pieces of English legislation. Its purpose was to prevent loss of revenue to the King as a result of freehold land being held by feoffees to the use of beneficiaries. The feoffees were the legal owners of the property, while the beneficiaries had the use and enjoyment of it. Provided the number of feoffees was maintained, no feudal incidents such as wardship, marriage or the payment of a relief would arise when the land passed from one generation of beneficiaries to another. ${ }^{13}$ To combat the loss of revenue to the Crown, the statute executed uses of freehold land where the feoffees had no active duties to perform, that is where they 'stood seised to the use of another'. The effect was to pass the seisin, the legal title to the freehold land, from the feoffees to the beneficiaries making them the legal owners and thereby ensuring that feudal incidents would be payable by them as the land passed from generation to generation ${ }^{14}$.

One impact of this policy was either foreseen or recognized very swiftly. It was that the statute could be used to convey land secretly from one person to another, making it difficult to keep track of who were the legal owners from whom the feudal incidents should be sought. No formality attended the creation of a use, and,

${ }^{13}$ The relief was a sum fixed by law which was payable by an heir on taking possession, or seisin, of freehold land in succession to a deceased relative. More importantly for the royal revenue, if the heir were under age and the land held by a military tenure, the wardship of the heir's land would be enjoyed by the Crown while the heir remained a minor, and this entitled the Crown to keep the profits. Where the infant heir was a female, the Crown also enjoyed the incident of marriage, that is the right to give the girl in marriage. This would often be to the highest bidder.

${ }^{14}$ The statute in effect confirmed in legislation the consequence of the judicial decision in the case of Lord Dacre of the South the previous year, where it had been held that the beneficiaries under a use could only enjoy the same interest in the land as that held by the feoffees. It would appear that that decision was in part the result of political pressure placed upon the judges by the royal government (see Baker 1978, 92-203). Dacre's case is discussed at pp. 200-202, and its significance for the statute on pp. 202-203. The political pressure placed on the judiciary is dealt with at p. 140. Spelman's report of Dacre's case can be found in Baker 1977, 228-230. 
as a consequence of the statute, if the feoffees had no active duties to perform, the beneficiaries immediately became legal owners without any form of publicity. This impact was addressed by the Statute of Enrolments passed in the same year which provided for the enrolment, that is the registration, of agreements to sell freehold land, thus ensuring that there was a record of who was the legal owner (Kaye 1988).

The consequences of a further impact, however, were either not foreseen or not fully appreciated. Putting land to uses had enabled freeholders to achieve something which the common law did not allow, namely the giving of land by will on the owner's death. Where the land was vested in feoffees, they could hold the land for the benefit of a beneficiary during his lifetime and then hold it for the benefit of anyone whom he chose after his death. The legal ownership was unchanged, only the right to enjoy the use of it. The execution of the use by the statute meant that this device could no longer be employed to the great inconvenience and dislike of landowners, many of whom had increased their landed wealth as a consequence of acquisitions made following the dissolution of the monasteries. The unpopularity occasioned by the loss of this device is thought to have contributed to a rebellion in the succeeding years known as the Pilgrimage of Grace. The royal government responded by passing the Statute of Wills in 1540 which, for the very first time, permitted freeholders to dispose of their land on death by means of a will - twothirds of their land in the case of those holding by military tenures and all in the case of others. One can legitimately regard the advent of the right to make a will of freehold land therefore as being occasioned by the impact of the Statute of Uses.

Some impacts, as is so often the case, were not apparent until much later. The ability of the Crown to ensure that its revenues from the feudal incidents were not lost meant that the King enjoyed an income which was not dependent upon taxes voted by Parliament. Indeed, it was an accepted principle of mediaeval government that the king should 'live of his own'. The efficacy of this in the century which followed was such that both Elizabeth I and James I were able to govern without calling Parliament for significant periods, and Charles I was able to govern without calling a Parliament for over a decade from 1629. That King's ability to govern without Parliament, however, undermined the constitutional arrangements which had been developing in England since the thirteenth century, and the tensions which resulted led to the Civil War. In turn, to prevent such a situation arising again, upon the Restoration of the monarchy in 1660, the Tenures Abolition Act abolished the military tenures from which the lucrative feudal incidents arose, thereby making the King dependent upon Parliament for the fiscal means to govern. The impact of the Statute of Uses was far reaching. ${ }^{15}$

${ }^{15}$ Military tenures had been abolished during the preceding Commonwealth period (1649-1660), but the 1660 Act ensured that they would not be resuscitated as a result of the monarchy's Restoration. 
The impact of this policy and the legislation which delivered it is readily apparent. That is not always the case. That is why an awareness on the part of historians that policies and legislation can have impacts beyond the effects which they are intended to achieve is so important if their historical accounts are to reflect the whole truth.

\section{THE SARUM OATH AND THE LEGAL REFORMS OF HENRY II}

The Sarum Oath is a justly famous moment in the reign of William the Conqueror, although some have doubted its constitutional significance (Douglas 1964, 355-356). Faced with the threat of rebellion involving members of his own family, the King realized that if the knights invested with lands by his nobility obeyed their immediate overlords rather than the King, the foundations of his authority were in truth weak. Accordingly, at Salisbury in 1086, he convened an assembly at which he took an oath of allegiance from the freemen of his realm, thereby ensuring that his free subjects owed him a loyalty greater than the loyalty owed to their lords. The effect was to introduce a personal nexus of direct loyalty between the king and his free subjects, alongside the pre-existing tiered loyalty existing between lords and their tenants culminating in that owed by the barons to the king.

While it is probably the case that this was the effect which William sought to achieve, and that he might not have perceived in this any constitutional significance for his kingship, that does not mean that the impact of the policy might not have been to enable such a constitutional development. Following his conquest of England, he had granted his followers lands within the realm in return for their services, and the barons had done the same by granting land to the knights who would in return perform military services. The knights in turn had granted lands to free tenants who would perform agricultural services for their lords on their manors. At every level, land was given in return for services, but also at every level the tenants pledged loyalty to their lords and in return the lord promised to be a good lord to his tenants, one element of which as to hold a court at which any disputes or grievances could be adjudicated and a just result provided. The nexus of loyalty in return for justice existed alongside the nexus of land in return for services. However, if the free tenants owed the king allegiance over and above the loyalty they owed to their lords, what, it might be asked, were they to receive in return. It may be that the question did not arise when the policy of getting them to swear allegiance was instigated, but that does not mean that the question would never arise nor that it was not pertinent in the aftermath of the Sarum Oath.

It is, as so often with the impact of English legal developments, about eighty years later that one sees developments which appear to deliver the logical 
outcome of William's policy. It was his great-grandson, Henry II, who opened access to the king's court to his free tenants generally. In that they owed him allegiance, Henry as a good lord was obligated to provide them with justice, and that he did by framing remedies for their use within his courts, remedies which saw the birth of the common law, the law common to all his free tenants. Tellingly, as he did this, he began to describe himself not just as 'king' but as 'lord king', emphasizing the relationship of allegiance which had been created by his great-grandfather, albeit that the impact of the new relationship was only felt almost a century later (as to the background to Henry II's adoption of the style 'lord king' see Watkin 1997). ${ }^{16}$

\section{UNDESIRED IMPACTS AND PURPOSIVE INTERPRETATION}

Thus far, the examples chosen have involved the realization of potential impacts by later rulers or the judiciary, or have involved the reversal of deleterious impacts by legislative changes of policy. The question however must also be asked as to what, if any, is the rôle of the judiciary if an unforeseen impact threatens to undermine the achievement of a legislative goal. The answer to this question places in opposition two approaches to statutory interpretation discussed earlier - the literal and the purposive. The former approach would have the judges doing nothing to resolve the difficulty but leaving it to the legislature, while the latter would permit them to interpret or even develop the law in order to minimise if not eradicate the impact's undesired effects. Can and should an awareness that judges may be faced with such dilemmas inform the legal historian's work?

That judges are faced with such dilemmas is a recorded fact. Ralph de Hengham, himself one of the ablest drafters of statutes, is famously remembered when he was Chief Justice of the Court of Common Pleas for rebuking counsel who attempted to interpret a statutory provision in his presence, saying "do not gloss the statute; we know it better than you, for we made it" ("Ne glosez point le statut; nous le savons meinz de vous, quar nous le feimes": YB 33-35 Ed. I (RS) 83), but the words which follow are also significant: "one often sees one statute undo another". Better evidence of what is meant by impact as opposed to intended effect can hardly be furnished.

The question however is what should judges do in such a situation. If they are aware, as Hengham certainly was, that the undoing of the earlier statute by the later had not been intended, should they acquiesce in the undesired

${ }^{16}$ The time gap is remarkably similar to that which separates the removal of references to the former forms of action from writs of summons by the Common Law Procedure Act 1852 and Lord Atkin's speech in Donoghue v. Stevenson, discussed above. 
consequence and leave it to the legislature to correct the contradiction, or should they themselves take steps to achieve the underlying purpose of each enactment?

In modern times, judges only very sparingly employ the casus omissus principle. Its use has been demarcated most recently by Lord Nicholls in Inco Europe Ltd. v. First Choice Distribution. He said:

"A statute is expressed in language approved and enacted by the legislature. So the courts exercise considerable caution before adding or omitting or substituting words. Before interpreting a statute in this way the court must be abundantly sure of three matters: (1) the intended purpose of the statute or the provision in question; (2) that by inadvertence the draftsman and Parliament failed to give effect to that purpose in the provision in question; and (3) the substance of the provision Parliament would have made, although not necessarily the precise words Parliament would have used, had the error in the bill been noticed." ([2000] 1 WLR 586, 592)

While in modern times, the willingness of the judiciary to do this is confined to patent errors in the drafting, examples of a more generous approach to the correction of legislation can be discerned in the late thirteenth and early fourteenth centuries when the judges themselves according to their own testimony produced the statutory record. There are certainly instances there of a readiness to prevent not merely an error in one statute proving mischievous to the success of the underlying policy but of acting to prevent a later statute inadvertently undermining the policy of an earlier enactment.

There are two well-known instances of this. The first is the case in which Hengham CJ uttered the words quoted above about counsel not glossing a statute. In it, it had been argued that chapter 2 of the Statute of Westminster II 1285 had restricted the application of a rule in chapter 9 of the Statute of Marlborough of 1267 . Hengham was not prepared to allow the later statute to 'undo' the policy of the former, and therefore, as Plucknett observed, one had the 'remarkable spectacle' of the later statute being undone by the earlier (YB 21 \& 22 Edward I (RS) 397; Plucknett 1949, 72-73).

The second example also involves the Statute of Westminster II, but this time its first chapter, which provided remedies aimed to prevent a person who had been granted freehold land with the express intention that it should pass to his lawful descendants from alienating the land so as to defeat their expectations. Such grants to persons and the heirs of their bodies had been interpreted by the courts as grants conditional upon the birth of such an heir and allowed the grantee to alienate the land once an heir was born. Chapter 1 of the Statute of Westminster II, known by its opening words as De donis conditionalibus or simply De donis, gave the heir in such circumstances a remedy by which he could recover the land - the writ of formedon in the descender, together with other remedies to protect others who might succeed to the land from an alienation which went against the form of the gift, forma 
doni, hence formedon ${ }^{17}$. What was unclear however was for how long the land was to continue to descend from heir to heir before, if ever, one could lawfully alienate it. The author has argued elsewhere that what had been anticipated by De donis was that the arrangement would end when the grantor or his general heir was prepared to terminate the entail, as this type of grant was called, and convert it into a normal tenurial holding by receiving payment of a relief and accepting the homage and/or fealty of the grantee in tail or an heir of his body. At that point, the grantor or his heir would become the lord of the grantee or his heir and feudal services would become due from the tenement. Unfortunately for this policy, a later statute - the Statute Quia emptores of 1290 - put an end to thecreation of such new feudal arrangements, thereby making it impossible for the entail to be brought to an end and therefore making the entail perpetual. That this was not an intended effect of either statute but rather an unforeseen impact is, it is submitted, implicit from remarks made by Bereford CJ with regard to the intended duration of entails. He said:

"He that made the statute intended to bring within it not only the donees but also the issue in tail until the entail was fully accomplished in the fourth degree; and the fact that he did not do so by express words concerning the issue, was only due to his negligence..." (Bolland 1915, 176-177; Bolland 1916, 226)

The charge of negligence against 'he who made the statute' - whom we know to be Ralph de Hengham - is little if anything short of defamatory. Plucknett refused to put the problem down to negligence on the part of Hengham, preferring to believe that the text had been 'clumsily, perhaps hurriedly, amended' and that in the intervening quarter century 'the tradition may have been warped' (Plucknett 1949, 133-134). The author has argued elsewhere (Watkin 1991) that the more likely explanation is there was no need to provide in the statute for how long the entail should last; as long as it could be terminated by the parties, no statutory determination of length was required. It is far more likely that it was the impact of the provisions of Quia emptores upon entails that caused the problem, an impact which was not an intended effect of the later statute. Not surprisingly therefore, within a generation of the problem arising, the judges were seeking to implement the purpose of the enactments and not the impact of their combined effect. The extent to which the judges were prepared to go to achieve this forms

${ }^{17}$ S.F.C. Milsom has shown that writs to enforce the forma doni existed prior to De donis, but these were not used in the circumstances of a subsequent alienation as anticipated by the statute. The earlier writ to protect the gift in reversion was available where the issue in tail had died out, and the writ to protect the heir in tail was used in the perhaps exceptional circumstance where, the donor having remarried and made a settlement in tail upon the issue of the later marriage, the entailed property had been wrongly taken by the heir general, being the issue of the first marriage (see Milsom 1956, 391-397, reprinted in Milsom 1985, 223-229). For formedon in the remainder before De donis, see Brand 1975, 318-323, reprinted in Brand 1992, 227-232. 
the fascinating tale of the development of the rules allowing for the barring of entails by warranty, fine and the common recovery - a purposive response to an unintended impact.

\section{CONCLUSION}

Despite the best endeavours of drafters and legislators to assess the outcomes of their work, circumstances change and there is in any event a limit upon what human beings can foresee. The consequence is that legislation often has impacts which are other than the effects intended or foreseen. Sometimes those impacts are merely accepted; at other times, the legislator may legislate afresh to correct the situation. Sometimes, however, it is the judiciary which realizes - in both senses of the word - the impact, taking advantage of the opportunity afforded to develop the law when it is deemed propitious, or at other times exercising ingenuity to prevent outcomes occurring which are patently contrary to what is known to have been intended.

For historians of the law, this raises a question. Is the object of their study simply what has occurred - the impact, or does it extend to what was intended to occur, even where the impact was otherwise? The latter course is more readily pursued in relation to periods when the evidential record preserves what was intended as well as what occurred, but is both more difficult and therefore likely to be more speculative with regard to ages when the record is less abundant. To what extent should an awareness that effect and impact can be at variance inform the response of historians of the law when faced with puzzling developments, so as to ask not merely what is occurring, but why and how it is occurring, including what underlying, but possibly unstated, principles or concepts enable the developments to take place?

The stance taken by legal historians in relation to these issues shapes the very nature of legal history as a discipline. It has been the purpose of this paper to suggest that to limit the discussion to what can definitely be stated to have occurred is to ignore a known facet of legal development, namely that laws have impacts as well as intended effects, and that to ignore that facet prevents a full appreciation of what legal developments actually involved. That legal historians search for the truth is axiomatic, but recognition that the historical record does not contain the whole truth should not confine but rather kindle their efforts to discern what the whole truth may be. Legal history, as part of the history of ideas, must of necessity be more than simply "one ... thing after another". 


\section{BIBLIOGRAPHY}

Ashburner, Walter. 1933. Principles of Equity. Edited by D. Browne. $2^{\text {nd }}$ ed. London: Butterworths. Baker, John H. 1977. The Reports of Sir John Spelman: Part I. Vol. 93 for 1976. London: Selden Society.

Baker, John H. 1978. The Reports of Sir John Spelman: Part II. Vol. 94 for 1977. London: Selden Society.

Bolland, William C. 1915. Year Books of 5 Edward II (1311-1312). Vol. 31. London: Selden Society. Bolland, William C. 1916. Year Books of 5 Edward II (1312). Vol. 33. London: Selden Society.

Brand, Paul A. 1975. "Formedon in the Remainder before De Donis". Irish Jurist 10: 318-323.

Brand, Paul A. 1992. The Making of the Common Law. London \& Rio Grande: The Hambledon Press.

Douglas, David C. 1964. William the Conqueror. London: Eyre Methuen.

Kaye, John M. 1988. "A Note on the Statute of Enrolments 1536". Law Quarterly Review 104: $617-634$.

Maitland, Frederic William. 1909. The Forms of Action. Cambridge: Cambridge University Press. Martin, Jill E. 2001. Hanbury and Martin Modern Equity. 16 ${ }^{\text {th }}$ ed. London: Sweet \& Maxwell.

Miers, David R. Alan C. Page. 1990. Legislation. $2^{\text {nd }}$ ed. London: Sweet \& Maxwell.

Milsom, Stroud F.C. 1956. "Formedon before De Donis". Law Quarterly Review 72: 391-397.

Milsom, Stroud F.C. 1985. Studies in the History of the Common Law. London \& Ronceverte: The Hambledon Press.

Plucknett, Theodore F.T. 1949. Legislation of Edward I. Oxford: Oxford University Press.

Watkin, Thomas Glyn. 1977. "The Spirit of the Seventies". Anglo-American Law Review 6: 119 127.

Watkin, Thomas Glyn. 1991. "Quia emptores and the Entail: Subinfeudation and the Family Settlement in Thirteenth-Century England". Tijdschrift voor Rechtsgeschiedenis 59: 353-374.

Watkin, Thomas Glyn. 1997. "The Political Philosophy of the Lord King". In Communities and Courts in Britain 1150-1900. Edited by Christopher W. Brooks, Michael Lobban. 1-12. London and Rio Grande: The Hambledon Press.

\section{Thomas Glyn Watkin}

\section{SKUTECZNOŚĆ, ODDZIAŁYWANIE I ANGIELSKA HISTORIA PRAWA}

Streszczenie. Teoretycy prawa i polityki społecznej rozróżniają pojęcia skuteczności oraz wpływu praw i prawodawstw. Skuteczność dotyczy osiągania celów zamierzonych przez prawodawcę. Wpływ odnosi się do rzeczywistych konsekwencji. Niekiedy obie kategorie różnią się od siebie. Bywa, że dopiero po upływie długiego czasu wpływ zostaje doceniony. Kiedy indziej wpływ wymaga interwencji ze strony ustawodawcy czy działających rozmyślnie sędziów, tak aby skorygować nieprzewidziane bądź nieszczęśliwe skutki rozwiązania prawnego. Rozmiar sędziowskich interwencji nie zawsze jest oczywisty na podstawie zachowanych dokumentów. W artykule dowodzi się, że świadomość możliwości wystąpienia takiego zjawiska jest niezbędna, jeśli historia prawa ma przedstawiać całą prawdę na temat jego rozwoju.

Słowa kluczowe: historia prawa; ustawodawstwo; skuteczność; wpływ; sądownictwo; interpretacja; celowość. 